\section{Family Business Performance: A Perspective of Family Influence}

\author{
Catarina Afonso Alves ${ }^{1}$ \\ ${ }^{1}$ Guarda Polytechnic, Department of Management \\ and Economics, Guarda, Portugal
}

Ana Paula Matias Gama

${ }^{2}$ University of Beira Interior \& NECE - Research Center in Business Sciences, Management and Economics Department, Covilhä, Portugal

\begin{abstract}
Purpose - The purpose of this study is to analyze the relationship between family influence, measured through power, experience and culture (F-PEC) and family business (FB) performance. Performance is measured from a financial and non-financial perspective.
\end{abstract}

Design/methodology/approach - Empirical study using the quantitative method and data collected through a questionnaire, answered by 169 Portuguese family firms. The survey design was based on prior research of FB performance and the F-PEC questionnaire. The exploratory factor analysis and multiple linear regression models are used.

Findings - The results indicate a negative relationship between experience and financial performance, a positive association between a culture of family commitment and performance (financial and noneconomic goals), and a positive relationship between a culture of family values and non-economic goals. The results show the importance of agreement between the firm and the family goals. Family influence on FB performance cannot be seen only from a positive (stewardship theory) or a negative (agency theory) perspective.

Originality/value - Commitment increases financial performance and the achievement of non-economic goals (perpetuity and family assets). It is important to study how a culture of commitment leads to superior performance.

Keywords - Family business; Performance; Non-economic goals; F-PEC scale.
Received on

$10 / 23 / 2018$

Approved on

06/17/2019

Responsible editor:

Prof. Dr. Ilídio Tomás Lopes

Evaluation process:

Double Blind Review

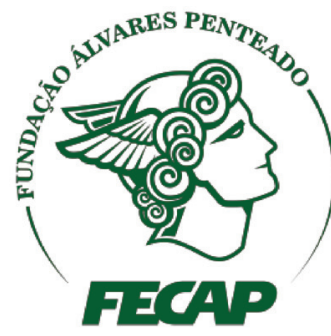

Review of Business

Management

DOI:10.7819/rbgn.v22i1.4040 


\section{Introduction}

Family businesses (FBs) constitute the predominant form of ownership in current markets (e.g., Carney, Van Essen, Gedajlovic, \& Heugens, 2015)and findings gleaned from publicly listed firms may not apply to the ubiquitous, but less frequently studied, privately held family firm (PFF). In Portugal, the Portuguese Family Businesses Association (AEF) estimates that over 60\% of Gross Domestic Product and 50\% of employment is generated by such companies, "with their ownership, whether totally or partially, in the hands of one or more family members, and the family [holds] control over the management of the company" (AEF, n.d.). The majority of smalland medium-sized companies (SMEs) are familyowned and their presence extends across various sectors of activity (AEF, n.d.). In this context, the FB emerges as a complex and heterogeneous entity due to the dynamics existing within the respective family and the different levels of influence that its members establish and maintain within the company (Gersick, Davis, Hampton, \& Lansberg, 1997), within the scope of which certain factors serve to moderate or influence this relationship (Miralles-Marcelo, Miralles-Quirós, \& Lisboa, 2014).

Research into FBs has focused upon how the family-owned status impacts on companies, especially in terms of their performance. According to some authors, the family dimension appears as a factor of weakness, especially because FBs tend to fail during the transition between generations (Gallo, 1995), with only 30\% of companies surviving the first generation (Beckhard \& Dyer, 1983; Ward, 1987). In Portugal, however, only $50 \%$ of $\mathrm{FBs}$ fail to make it down to the second generation (AEP, 2011; Lisboa, 2018). The family influence is described as a source of conflict and disorganisation (Donnelley, 2006; Kets de Vries, 1994) alongside references to a lack of professionalism and nepotism (Dyer, 1989). From a different perspective, Westhead and Howorth (2007) refer to how FBs attain greater longevity than non-family businesses (NFB), which derives from the commitments of the family in the long term and their strong sense of loyalty to the company (Denison, Lief, \& Ward, 2004).

Some research findings point to $\mathrm{FBs}$ achieving higher levels of financial performance than their peers (NFBs) (e.g., Anderson \& Reeb, 2003; Craig \& Dibrell, 2006; González-Cruz \& Cruz-Ros, 2016; Tsao, Chen, \& Wang, 2016), correspondingly explained by more effective management, reduced agency costs as a result of the overlap in the relationship between the owner (principal) and the manager (agent) of the company and the general long-term orientation of family ownership in conjunction with the system of values, the bond between the family and the business, and lower debt levels due to the risk aversion of family members (GomezMejia, Nuñez-Nickel, \& Gutierrez, 2001; Le Breton-Miller \& Miller, 2009). However, Schulze, Lubatkin, Dino, and Buchholtz (2001) take a different position as regards the implications of agency costs in FBs, warning of higher costs due to altruism and the ineffectiveness of control mechanisms that is characteristic of family-owned firms.

According to Tagiuri and Davis (1996), the results achieved by FBs show the interactions between the needs of the family and those of the company. These companies pursue goals that represent a combination of economic and financial goals, as with any other firm, and the non-economic goals that derive from family participation in the company (e.g., Chua, Chrisman, De Massis, \& Wang, 2018; Holt, Pearson, Carr, \& Barnett, 2017).

Observing the family group, Holt et al. (2017) identify non-economic outcomes associated with family group involvement (e.g., family cohesion - emotional and cognitive, feelings of belonging, trans-generational sustainability, family identity) and external perceptions of the family group (e.g., family image and prestige, community embeddedness, family legacy). From the company perspective, the non-economic 
outcomes interlink with the company's operations (e.g., employee satisfaction, organisational commitment, stewardship behaviours) and the external perceptions of the company (e.g., customer satisfaction, firm reputation and image, social responsibility). Chua et al. (2018) maintain that understanding just how these different systems (business and family) impact on performance (economic-financial and noneconomic) is fundamental to ensuring the longevity of a family business.

Despite the recognised importance of nonfinancial goals to FBs (Chrisman, Chua, Pearson, \& Barnett, 2012; Chua et al., 2018), there are only a handful of studies on this theme.

The objective of this article is thus to analyse the relationship that exists between the level of influence of the family on levels of FB performance from both the financial and the non-financial perspectives. In order to measure family influence, we applied the scale developed by Astrachan, Klein and Smyrnios (2002), which measures family influence $(F)$ across three dimensions: power $(\mathrm{P})$, experience $(\mathrm{E})$ and culture (C) - the F-PEC scale.

The objective of this research is to contribute to the theoretical framework on FBs using the following approach: (1) measure "family influence" using the F-PEC scale developed by Astrachan et al. (2002) and (2) observe performance from a perspective that considers non-economic objectives and financial performance.

Furthermore, this article focuses on the family influence in companies through adopting not only the financial dimension but also non-financial objectives. Also, we take into account the long-term involvement of the family in the ownership and management of the company in order to reflect the respective levels of commitment (Rau, Astrachan, \& Smyrnios, 2018), which are attributes that, according to Chrisman et al. (2012), establish a necessary condition for determining the familiness of the company.
The structure of the article is as follows. Section two presents a literature review of family influence (F-PEC) and performance as well as setting out the respective research hypotheses. Section three describes the sample, the methodology and the variables used. The results and our analysis feature in section four. Section five presents the conclusions, emphasising the study's contributions both in theoretical fields and as regards the implications for economic agents.

\section{Literature Review and Research Hypotheses}

\section{I The family influence}

Traditionally, the definition of FBs involves one or more members of a family wielding considerable control over the company, due to their significant percentage of ownership (capital) (Allouche \& Amann, 2000). For Tagiuri and Davis (1996, p. 203), maintaining FBs relies on three pillars: direction/management, family and ownership. According to these authors, "there are two or more extended family members who influence the direction of the business through the exercise of kinship ties, management roles, or ownership rights". Meanwhile, Chua, Chrisman and Sharma (1999) define a FB as one that is managed on the basis of handing down the firm from generation to generation in order to obtain a formal or implicit vision of the business as the property of a single family or a small number of families. Furthermore, Gallo and Ribeiro (1996) consider that FBs embody an important interconnecting bond between the company and the family and that part of this shared culture stems from basic assumptions regarding actions and values, where this culture is not only permanent but also voluntarily shared.

According to Chua et al. (1999), the uniqueness of $\mathrm{FBs}$ arises from the family itself: "what makes a family business unique is that the pattern of ownership, governance, management, and succession materially influences the firm's 
goals, strategies, structure, and the manner in which each is formulated, designed, and implemented" (Chua et al. 1999, p. 22).

Additionally, Shanker and Astrachan (1996) and Astrachan and Shanker (2003) differentiate family firms from the involvement of family members in business decision making. Along these same lines, Astrachan et al. (2002) develop a measurement scale (the F-PEC scale) that measures the level of family influence in any organisation considering three dimensions: power $(\mathrm{P})$, experience $(\mathrm{E})$ and culture $(\mathrm{C})$. According to Astrachan et al. (2002), the purpose of F-PEC extends beyond characterising family-owned or non-family-owned companies in order to identify the level of involvement and influence of the family in the company.

\section{I.I F-Power Dimension}

In the power dimension, family members enact their influence through involvement in the ownership, the governance and the management of FBs. Their influence through ownership is exercised by their participation in the company capital, and their influence through governance and management is evaluated by the representativeness of the family on the governance and management boards.

According to Astrachan et al. (2002), family members may have different levels of involvement due to the number of shares/quotas they own, or the seats held on the management board. Across this dimension, agency theory and stewardship theory may help in grasping the (positive or negative) influence that the family maintains over the company, especially in terms of its performance (e.g., Madison, Holt, Kellermanns, \& Ranft, 2016) .

We note that text on agency theory has been introduced which is not in our original version. It should be deleted and the paragraph replaced by

"The agency theory is based on the separation between company ownership (principal) and the manager (agent), implying that the shareholders (owners) hold only limited control over managers' decisions while they have a priori divergent interests and risks preferences (Jensen \& Meckling, 1976) which may lead to a relationship with potential conflicts of interest between the parties. Hence, the use of monitoring and control mechanisms allows shareholders to protect their investments. In stewardship theory, the agent (manager) adopts behaviours that are better oriented towards the interests of the organisation (pro-organisational orientation) based on mutual trust. In this distinct logic, stewardship theory highlights the scope for congruence among the targets in effect for owners and managers and going beyond merely individualist and economic goals (Davis, Schoorman, \& Donaldson, 1997).

\section{I.2 F-Experience Dimension}

This dimension incorporates the ways in which the family influence stems from the experience and knowledge built up over the course of the successive generations involved in the business (Klein, Astrachan, \& Smyrnios, 2005).

According to Astrachan et al. (2002), FBs that survive through to the succession of the following generation obtain "gains" in terms of the accumulated experience. These authors maintain that the succession experience curve generates the greatest growth (gains) in the transition from the first to the second generation, with a weakening in the effects for subsequent generations.

In addition to the generation(s) involved, the number of family members actively participating in the company represents an important indicator of the experience accumulated through incorporating family members.

\section{I.3 F-Culture Dimension}

One of the truly distinctive elements of FBs comes from the role of the family's own culture in the company (Gallo, 1995). In the culture dimension, the F-PEC scale attempts to estimate the extent to which the family values and the company values coincide and thus 
determine the level of family commitment in the company. According to Carlock and Ward (2001), family commitment involves three factors: a conviction and support for the goals and vision of the company, willingness to contribute to the organisation and the desire to belong to the organisation. In summary, the greater the family's commitment to the company, the greater the influence exerted by the family on the company's performance.

According to Gersick et al. (1997), company culture may persist over a long period of time with few changes whenever there are norms in place for transferring its essence, as in the case of FBs, in which the family represents one of the most reliable social structures for conveying cultural values and practices down through generations.

\subsection{Family firm performance}

In organisations, performance constitutes a multidimensional concept, where both the economic-financial and non-economic factors need to be considered when measuring performance, particularly in FBs, in which noneconomic objectives are prominent (e.g., Basco, 2017; Madison et al., 2016; Williams, Pieper, Kellermanns, \& Astrachan, 2018)antecedents. In these companies, there are concerns not only about financial aspects but also the needs of the family (Chua et al., 2018). Therefore, decisions tend to act to protect the family's identity, its reputation and to ensure the perpetuation of its values along with the company capital, among other factors, even when this may on occasion harm the performance of the business (Zellweger, Nason, Nordqvist, \& Brush, 2013).

From the agency theory perspective, family ownership and management rank as dimensions in a system in which the (rational) economic objectives, such as the maximisation of profits, are openly assumed (Jensen \& Meckling, 1976). However, the dynamic of the "family" system in companies with closed-capital structures may increase the complexity of family ownership and management, especially whenever there are incongruences between the "family agenda" and behaviours in which non-economic objectives tend to prevail. Furthermore, stewardship theory suggests that closed-capital FBs, which display a lack of external representation or influence, adopt a culture of service to the organisation and a correspondingly greater emphasis on noneconomic goals.

Consequently, performance research should not be limited to studying strictly financial performance, due to the involvement of the family, in which the goals and objectives of FBs naturally differ from those of NFBs (e.g., Aparicio, Basco, Iturralde, \& Maseda, 2017). Williams et al. (2018) state that FBs display a propensity to choose strategies to achieve family-based goals (e.g., control, low debt levels).

Within this framework, we can quote Chua, Chrisman and Steier (2003): "for a business to be sustainable as a family firm in the highly competitive global market of the twenty-first century, there must be a synergistic and symbiotic relationship between the family and the business ... a paradigm for family firms would have to expand its goal set to include benefits unrelated to financial and competitive performance" (Chua et al., 2003, pp. 331-333).

\subsection{Research hypotheses}

Taking into account the heterogeneous reality of FBs, Chua, Chrisman and Chang (2004) consider that there are different levels of influence and involvement in companies. Astrachan and Zellweger (2008) recommend an individual approach to the dimensions of F-PEC in order to obtain a more differentiated representation of how the family affects performance through different levels of influence.

For the power dimension, the family's involvement stems from its participation in the ownership (family in ownership - FIO) and the management (family in management - FIM). These two areas have returned controversial results when seeking to establish relationships between 
family involvement and company performance (Carney et al., 2015; Kowalewski, Talavera, \& Stetsyuk, 2009; Sciascia \& Mazzola, 2008). In unlisted companies, research has indicated the absence of any relationship between FIO and performance (O’Boyle Jr., Pollack, \& Rutherford, 2012; Westhead \& Howorth, 2006), and a negative relationship between FIO and performance (Rutherford, Kuratko, \& Holt, 2008). However, the long-term perspective of FBs, which derives from the intention to transfer ownership to the following generation, encourages owners to suffer less from business myopia (Sciascia \& Mazzola, 2008) and investments are more efficient to better monitor the activity of managers (Jensen \& Meckling, 1976). As regards family participation in company management (FIM), the benefits of such family management derive from the stewardship behaviours of managers who act in the interests of owners (Corbetta \& Salvato, 2004). The positive relationship between family management and financial performance arises from the family's commitment to the company (Dyer, 2006), and this involvement in management is likely to reduce agency problems when family managers act as agents in order to improve performance (Chrisman, Chua, Kelermanns, \& Chang, 2007). Within the FB context, in which family members share both ownership and management, we may thus formulate hypothesis $1 \mathrm{a}$ :

H1a: The family influence, through involvement in the ownership, the governance and the company's management, is positively associated with economic and financial performance.

As regards attaining non-economic objectives, the literature shows that family ownership/management is favourable to attaining the objectives of family members in relation to the company and to the family itself (Holt et al., 2017; Westhead \& Howorth, 2006). The literature on socioemotional wealth highlights the relevance of nonfinancial objectives to the performance of FBs and defines this "as nonfinancial aspects of the firm that meet the family's affective needs, such as identity, the ability to exercise family influence, and the perpetuation of the family dynasty" (Gomez-Mejia, Haynes, Núñez-Nickel, Jacobson, \& Moyano-Fuentes, 2007 , p. 106). Thus, hypothesis $1 \mathrm{~b}$ proposes:

H1b: The family influence, through involvement in the ownership, the governance and the company's management, is positively associated with non-economic objectives.

As regards the experience gained in the succession process, it is recognized that the experience curve sees strong growth between the first and second generation, where many of the new "rituals" are established, and is attenuated in subsequent generations contributing a proportionally smaller value to this process (Astrachan et al., 2002; Klein et al., 2005).

In effect, the research findings reveal significant differences in FB profitability depending on the generations involved in ownership and management (Kellermanns, Eddleston, Sarathy, \& Murphy, 2010). Hence, companies with greater levels of generational dispersion may display lower levels of profitability as a result of the reduced propensity for risk in an attempt to minimise the risks of failure. As a new generation adopts an active role in the company, the family members become more distant from the founding generation, which acts to weaken the family bonds and the commitment towards the founder's vision. A greater dispersion in the generations may also generate rivalries among family members that divide the family group and subsequently impact on company performance (Kellermanns et al., 2010). When the company evolves into a multi-generational firm, despite the gains in knowledge, a more formal structure is needed in order to guarantee company sustainability, reducing the risk of loss of family cohesion and avoiding divergences in the family 
values and commitments (Aronoff, Astrachan, \& Ward, 2002).

Given these findings from the literature, we set out the following hypotheses:

H2a: A higher level of generational dispersion is negatively related to economic and financial performance.

H2b: A higher level of generational dispersion is negatively related to noneconomic objectives.

The financial supremacy of FBs does not necessarily stem from their better adaptation to the surrounding economic environment but certainly incorporates the existence of a set of pre-established cultural values and norms. When a family recognises its own interests and integrates them with more advantageous objectives for the business, major benefits may accrue due to the fact that the owners and the other family members hold shared interests and objectives (Donnelley, 2006; Bertrand \& Schoar, 2006). Thus, in their comparison between FBs and NFBs, Denison et al. (2004) conclude that culture enables gains in performance, with family involvement emerging as a distinctive variable.

Within this scope, the culture of family and company values reveals how the company strengthens through a culture of commitment to perpetuating the business (Astrachan et al., 2002; Gallo \& Ribeiro, 1996; Ward, 1987; Zellweger et al., 2013), which is a factor that is able to achieve higher levels of performance (e.g., Zahra, Hayton, Neubaum, Dibrell, \& Craig, 2008).

Within this context, we may formulate the following hypotheses:

H3a: A culture of commitment is positively associated with economic and financial performance.

H3b: A shared culture of values between the family and the business is positively associated with economic and financial performance.

H3c: A culture of commitment is positively associated with non-economic objectives.

H3d: A shared culture of values between the family and the business is positively associated with non-economic objectives.

\section{Sample, Methodology and Variables}

\section{I Sample}

The sample contains 804 family-owned and unlisted SMEs registered on an annual list of Portuguese companies, the "Estatuto PME líder” list published by IAPMEI - the Support Institute for Small- and Medium-Sized Companies and Innovation. We collected the data via a questionnaire sent out directly to the postal addresses of FBs whose headquarters were in mainland Portugal. Furthermore, we applied the following definition of FB: "the company is classified as a family-owned business when it obtains a degree of involvement in various dimensions of the company (e.g., ownership, management, experience and culture) of at least 50 percentage points on the F-PEC scale". This definition integrates components involving the family's influence (Astrachan et al., 2002; Klein et al., 2005), enabling the company to obtain a different ranking across each one of the dimensions. We received 169 valid questionnaires corresponding to a response rate of $21 \%$, an acceptable value in this research field (e.g., Chrisman et al., 2012).

The sample companies report an average percentage of family ownership of $97 \%$, with $89 \%$ having exclusively family-owned structures (100\% of the capital) and family members being solely responsible for the management of $78 \%$ of these companies. In summary, the data reveal a high concentration both of family ownership and family management. The average age of the 
companies is 38 years. Furthermore, $97 \%$ indicate the intention to maintain control over company ownership for the next five years.

In generational terms, the next change in leadership is still to occur in $45 \%$ of these companies, where the ownership rights are exclusively held by the founder. This is followed by companies integrating the second, third and four generation of owners, representing 36\%, 13\% and $6 \%$ of the companies, respectively.

\subsection{Methodology}

In the first phase, univariate analysis enabled the characterisation of the data while evaluating the applicability of the following statistical techniques: exploratory factor analysis (EFA), Cronbach's alpha coefficients, multiple linear regression (MLR) models and Pearson's correlations. EFA serves to: (i) obtain the factors that measure the dependent variables for performance and the independent variables for family influence (via the F-PEC scale), followed by analysis adopting Cronbach's alpha coefficients; (ii) include the EFA factors into the regression analysis; (iii) overcome any problems with multicollinearity in the MLR. EFA stems from pre-established procedures for verifying the appropriateness of the data: observation of the correlation matrix, measurement of the sampling adequacy (MSA), and interpretation by the Bartlett sphericity test and the Kaiser-MeyerOlkin (KMO) statistic. The criteria for retaining the factors adopted were, simultaneously, (1) eigenvalues greater than one, (2) percentage of explained variance greater than 60\%, and (3) observation of the scree plot. The allocation of a variable to a given factor resulted from rotating the solutions according to the varimax method.

\section{$3 \cdot 3$ Variables}

\subsection{Dependent variables}

Economic-financial performance: to measure financial performance (for the last three years) in relation to the competition, we applied a 5-point Likert scale ranging from 1 (well below the main competitors) to 5 (well above the main competitors), composed of six items (see appendix A) (e.g., Allouche, Amann, \& Garaudel, 2007; Castillo \& Wakefield, 2007; Craig \& Dibrell, 2006; González-Cruz \& Cruz-Ros, 2016; Sciascia \& Mazzola, 2008).

Non-economic objectives: this variable is measured by 10 items (see appendix A) (Chua et al., 1999; Westhead \& Howorth, 2007; Zellweger, Halter, \& Frey, 2006), applying a 5-point Likert scale varying from 1 (not at all important) to 5 (highly important).

After observing the EFA procedures, we verified that the 13 variables ${ }^{1}$ measuring performance result from retaining three factors (Table 1): economic and financial performance (EFP) and two variables relating to non-economic goals: medium-and long-term goals (MLTG) and family wealth (FAMWEA). 
Table 1

\section{EFA results for performance}

\begin{tabular}{lc}
\hline Performance & Factor loadings \\
\hline Kaiser-Mayer-Olkin (KMO): .774; variance explained: 60.94\% & .909 \\
\hline Factor 1- Economic-financial performance (EFP) (eigenvalue: 3.879; Cronbach's alpha: .900) & .885 \\
\hline Net return on assets & .856 \\
\hline Return on equity & .792 \\
\hline Operating profit margin & .762 \\
\hline Growth in market share & .831 \\
\hline Sales growth & .698 \\
\hline Factor 2- Medium- and long-term goals (MLTG) (eigenvalue: 2.865; Cronbach's alpha: .697) & .670 \\
\hline Assure long-term survival of the business & .631 \\
\hline Reduce debt & \\
\hline Promote business growth & .745 \\
\hline Stay independent & .651 \\
\hline Factor 3- Family wealth (FAMWEA) (eigenvalue: 1.178; Cronbach's alpha.661) & .540 \\
\hline Increase private or family wealth & \\
\hline Prepare and train a successor & \\
\hline Reduce capital dispersion, ensuring its concentration in the family group & \\
\hline Increase the market value of the company & \\
\hline
\end{tabular}

\subsubsection{Independent variables}

The independent variables feature the three dimensions that make up the F-PEC scale (see appendix B) and were obtained in accordance with the procedures applied by Astrachan et al. (2002), Klein et al. (2005) and Holt, Rutherford and Kurakto (2010).

Power: formed of 3 items: ownership, governance and management, measured as percentages.

Experience: measured across the 3 items that represent the generational benefits to the (1) ownership, (2) management, (3) and governance of the company. In keeping with the F-PEC procedures, the first generation is re-codified as 0 (absence of any generational experience benefits), the second generation as 50 , the third generation as 75 , the fourth as 87.50 and so forth.

Culture: represented by two sub-scales, with the first made up of 3 items that measure the overlap between the family culture and that of the company through the application of a 5-point Likert scale ranging from 1 (never) to 5 (always), and with the second sub-scale measuring the family commitment in relation to the company through the evaluation of 9 items, again measured by a 5 -point Likert scale varying from 1 (totally disagree) to 5 (totally agree).

The EFA with 17 variables $^{2}$ deploys four factors (Table 2) to span the family influence in FBs: power, experience, culture of commitment and the culture of values. The inclusion of two factors for the cultural dimension diverges from the results obtained by Klein et al. (2005) and Holt et al. (2010). However, here we consider that obtaining two factors for the culture dimension (i.e., culture of commitment and culture of values) is conceptually valid and coherent with FB theory (e.g., Rau et al., 2018). 
Table 2

\section{EFA results for family influence}

\begin{tabular}{|c|c|}
\hline Family influence & \\
\hline Kaiser-Mayer-Olkin (KMO): .801; variance explained: 69.055\% & \\
\hline Factor 1- Culture of commitment (eigenvalue: 5.384; Cronbach's alpha: .890) & Factor loadings \\
\hline I understand and support my family's decisions regarding the future of the family business & .802 \\
\hline Deciding to be involved with the family business has a positive influence on my life & .796 \\
\hline Family members feel loyalty to the family business & .792 \\
\hline Family members are proud to tell others that they are part of the family business & .777 \\
\hline Family members agree with the family business' goals, plans and policies & .755 \\
\hline $\begin{array}{l}\text { Family members are willing to put in a great deal of effort beyond that normally expected to help the family } \\
\text { business be successful }\end{array}$ & .732 \\
\hline Family members really care about the fate of the family business & .673 \\
\hline There is so much to be gained by participating in the family business on a long-term basis & .576 \\
\hline Factor 2 - Experience (eigenvalue: 2.795; Cronbach’s alpha: .933) & \\
\hline Generation (s) of company ownership & .954 \\
\hline Generation (s) active on the company's governance board & .954 \\
\hline Generation(s) actively managing company operations & .897 \\
\hline Factor 3 - Culture of values (eigenvalue: 2.102; Cronbach's alpha: .795) & \\
\hline Family and business share similar values & .860 \\
\hline Family members share similar values & .854 \\
\hline Family has an influence on the business & .724 \\
\hline Factor 4 - Power (eigenvalue: 1.459; Cronbach's alpha: .692) & \\
\hline Percentage of family on the Board & .888 \\
\hline Percentage of family share ownership & .886 \\
\hline Percentage of family management team & .724 \\
\hline
\end{tabular}

\section{$3 \cdot 3 \cdot 3$ Control variables}

The control variables are the legal form, dimension, internationalisation and the founder's presence in the management.

The legal form takes into account the respective corporate governance configurations (Klein, 2010). When the company grows in scale, the choice of legal form plays a crucial role in determining the establishment of the norms and regulations for decision making (Fahed-Sreih, 2009). This dummy variable breaks down into two categories $(1=$ public limited company, $0=$ private limited company).

The company size is defined as a dummy variable $(1=$ medium company, $0=$ other cases) following the European Commission Recommendation of 6 May 2003 [COM 2003/361/CE] for the classification of SMEs.
Companies have to deal with increasingly competitive environments in relation to their internationalisation processes (Corbetta \& Montemerlo, 1999; Merino, Monreal-Pérez, \& Sánchez-Marín, 2015). The greater the scope of company internationalisation, the greater the (potential) impact on performance (Kellermanns et al., 2010; Sciascia \& Mazzola, 2008). This dummy variable takes the value of 1 for exporting company and 0 for other cases.

The founder's involvement in company management is represented by a dummy variable. When the founder still assumes the position of manager, even if shared with the successor generation, this tends to lead the company to better performance (Anderson \& Reeb, 2003; Maury, 2006; Villalonga \& Amit, 2006). 


\section{Presentation and Discussion of the Results}

\section{I Results}

Table 3 presents the results for each of the three MLR models ${ }^{3}$ estimated.

Table 3

Regression model results *

\begin{tabular}{|c|c|c|c|c|}
\hline & & \multirow{2}{*}{\multicolumn{3}{|c|}{ PERFORMANCE }} \\
\hline & & & & \\
\hline & & $\begin{array}{c}\text { EFP }^{a} \\
\text { MODEL I }\end{array}$ & $\begin{array}{c}\text { MLTG }^{\mathbf{b}} \\
\text { MODEL II }\end{array}$ & $\begin{array}{l}\text { FAMWEA }^{c} \\
\text { MODEL III }\end{array}$ \\
\hline & & Coefficient $\beta$ & Coefficient $\beta$ & Coefficient $\beta$ \\
\hline (constant) & & $\begin{array}{c}-, 085 \\
(-, 501) \\
\end{array}$ & $\begin{array}{c}-, 089 \\
(-, 524) \\
\end{array}$ & $\begin{array}{l}, 162 \\
(, 971) \\
\end{array}$ \\
\hline \multicolumn{5}{|l|}{ Control variables } \\
\hline legal form & & $\begin{array}{l}-, 095 \\
(-, 542)\end{array}$ & $\begin{array}{l}-, 028 \\
(-, 160)\end{array}$ & $\begin{array}{l}, 012 \\
(, 069)\end{array}$ \\
\hline Size & & $\begin{array}{l}, 130 \\
(, 761)\end{array}$ & $\begin{array}{c}, 176 \\
(1,019)\end{array}$ & $\begin{array}{c}, 202 \\
(1,201)\end{array}$ \\
\hline Internationalisation & & $\begin{array}{c}, 586^{* *} \\
(3,399)\end{array}$ & $\begin{array}{l}, 108 \\
(, 625)\end{array}$ & $\begin{array}{c}-, 251 \\
(-1,480)\end{array}$ \\
\hline Founder in management & & $\begin{array}{l}-, 696^{* *} \\
(-3,289)\end{array}$ & $\begin{array}{l}-, 082 \\
(-, 387)\end{array}$ & $\begin{array}{l}-, 113 \\
(-, 545) \\
\end{array}$ \\
\hline \multicolumn{5}{|l|}{ Independent variables } \\
\hline Power & & $\begin{array}{l}-, 072 \\
(-, 932)\end{array}$ & $\begin{array}{l}-, 046 \\
(-, 583)\end{array}$ & $\begin{array}{c}, 100 \\
(1,310)\end{array}$ \\
\hline Experience & & $\begin{array}{c}-, 217^{*} \\
(-2,031)\end{array}$ & $\begin{array}{c}-, 163 \\
(-1,517)\end{array}$ & $\begin{array}{l}, 044 \\
(, 416)\end{array}$ \\
\hline Culture of commitment & & $\begin{array}{l}, 130^{\dagger} \\
(1,728)\end{array}$ & $\begin{array}{c}, 216^{* *} \\
(2,847)\end{array}$ & $\begin{array}{l}, 334^{* * *} \\
(4,502)\end{array}$ \\
\hline Culture of values & & $\begin{array}{c}, 046 \\
(, 616) \\
\end{array}$ & $\begin{array}{c}, 214^{* *} \\
(2,864) \\
\end{array}$ & $\begin{array}{c}, 140^{\dagger} \\
(1,927)\end{array}$ \\
\hline & $\mathrm{R}^{2}$ &, 131 & ,119 &, 159 \\
\hline & $\mathrm{R}^{2}$ adjusted &, 088 & 075 &, 117 \\
\hline & $\mathrm{F}$ & $3,024^{* *}$ & $2,700^{* *}$ & $3,787^{* * *}$ \\
\hline
\end{tabular}

Note. $\ddagger$ Non-standardized coefficients. a) EFP - economic and financial performance; b) MLTG medium- and long-term goals; c) FAMWEA - family wealth.

$\dagger \mathrm{p}<.10 ;{ }^{*} \mathrm{p}<.05 ;{ }^{* *} \mathrm{p}<.01 ;{ }^{* * *} \mathrm{p}<.001$.

The results demonstrate that the three models are statistically significant: (i) model I explains $8.8 \%$ of the variance as regards EFP (R2a $=.088 ; \mathrm{F}=3.024 ; \mathrm{p}<.01$ ); (ii) model II accounts for $7.5 \%$ of the variance in MLTG $(\mathrm{R} 2 \mathrm{a}=.075$; $\mathrm{F}=2.700 ; \mathrm{p}<.01$ ); and (iii) model III explains $11.7 \%$ of the variance in the case of FAMWEA $(\mathrm{R} 2 \mathrm{a}=.117 ; \mathrm{F}=3.787 ; \mathrm{p}<.001)$.

The internationalisation control variable is positive and statistically significant only in model
I $(\beta=.586 ; p<.01)$. Concerning the control variable "founder's presence in the management", there is a negative and statistically significant relationship with EFP $(\beta=-.696 ; \mathrm{p}<.01)$.

\subsection{Discussion}

\subsection{Economic and financial performance}

Model I reports a positive and statistically significant relationship between a culture of 
commitment and the EFP of FBs $(\beta=.130 ; \mathrm{p}<$ $.10)$, a result that validates hypothesis $3 a)$. Hence, the greater the level of family commitment to the company, the greater the level of the "perceived" EFP. This conveys how the presence of a strong culture of commitment enables the individual interests of family members through behaviours such as loyalty, pride, and a feeling of belonging to the company, which guide their decisions towards higher performance. These results converge with stewardship theory and align with those reported by Eddleston, Kellermanns and Sarathy (2008) and Patel and Kellermanns (2010). A culture of commitment enables FBs to consolidate their reputation and cope with lower transaction costs, consequently guaranteeing their market presence in a longer-lasting and more durable approach (Sharma et al., 1997).

As regards the experience variable, we obtained a statistically significant negative relationship at $5 \%(\beta=-.217 ; \mathrm{p}<.05)$. This result confirms hypothesis $2 \mathrm{a}$ ). FBs, as any other organisation, face challenges over the course of their maturing business cycles. Experience increases as new generations integrate into the ownership and management of the company. If, on the one hand, the intergenerational transition brings benefits to the level of knowledge incorporation (the succession experience curve), on the other hand, higher levels of generational dispersion alter the ownership structure, and the relationships between family members are potentially more conflictual, which may have negative effects on performance. The fact that our sample contains FBs with an average age of 38 years, where the second and third generations are present in the ownership and management of the companies, may explain this result. The negative impacts of generational transitions and dispersion coincide with the findings of Zellweger (2006), Astrachan and Zellweger (2008) and Kellermanns et al. (2010), which report how multi-generational companies achieve lower levels of performance.

The results for the power and culture of values variables do not display any statistically significant association $(\beta=-.072 ; \mathrm{p} \geq .10 ; \beta=.046$; $\mathrm{p} \geq .10$, respectively) with EFP, so hypotheses $1 \mathrm{a}$ ) and $3 \mathrm{~b}$ ) are not supported. These results suggest that family power and a culture of values are not relevant to explaining EFP.

\subsection{Medium- and long-term objectives and family wealth}

A culture of commitment $(\beta=.216$; $\mathrm{p}<.01)$ and culture of values $(\beta=.214$; $\mathrm{p}<.01)$ show a positive and statistically significant relationship with MLTG. Model III also shows similar results, in which a culture of commitment $(\beta=.334 ; \mathrm{p}<.001)$ and culture of values $(\beta=.140 ; \mathrm{p}<.10)$, even if with a weaker level of significance in the latter case (10\%), present positive associations with the FAMWEA objectives, results that corroborate hypotheses 3c) and 3d).

FBs are particularly successful in noneconomic objectives whenever they have a strong culture of commitment and values. Hence, family members should ensure a balance between a culture of commitment and values and the prevailing objectives for both the company and the family (Aparicio et al., 2017; Labaki, 2007).

In $\mathrm{FBs}$, the identity is reflected in the sharing and alignment of values among the family members participating in the company. This cohesion of family-company values occurs when family members, through their participation, accept the mission and values of the company as their own. The greater the level of this cohesion, the greater the willingness of family members to strive for objectives such as the continuity and independence of the company (Zahra et al., 2008). These results also fall within the scope of the stewardship perspective, which focuses on the overlap between company values and family values. A culture of commitment and values reveals a greater explanatory power in the noneconomic objectives compared to the EFP.

Finally, both the power and experience variables do not display any statistically significant association with MLTG (model II) and similar 
results are obtained with FAMWEA (model III). These results do not support hypotheses $1 \mathrm{~b}$ ) and $2 \mathrm{~b}$ ). This indicates how participating in the company ownership and management does not in itself determine whether the FB's non-economic objectives are met.

Similarly, the results found also confirm the inexistence of any relationship between experience and non-economic objectives; hence, any displacement between the family members and the founding generation (weakening the family bonds) does not necessarily compromise the company's perpetuity goals. This result is explained by the longevity that characterises our sample (38 years) and by the lower impact of additional experience as regards generational dispersion.

\section{Conclusions}

Using the F-PEC survey proposed by Astrachan et al. (2002) and Klein et al. (2005), a sample of 169 family-owned SMEs was collected, which enabled four dimensions to be studied: power, experience, culture of commitment and culture of values. Despite the latter two not establishing a single dimension (contrary to the approach by Klein et al. (2005)), we opted to study them separately due to their theoretical importance.

The results ensured the identification of a negative relationship between experience and company EFP. This was also concluded from the existence of a positive, although weak relationship between the culture of commitment and EFP. The relationships established for the power and culture of values variables regarding EFP were not verified. These unexpected results can be explained by the specificity of our sample, which involves an average age of 38 years, showing a long maturity of the family and company life cycle. However, despite the longevity of the companies, we can also report that the founders retain high levels of presence, both in terms of company ownership and management. Family ownership in 65\% of the companies has already moved, whether partially or totally, to the second generation, while the founder still holds a capital stake in $61.5 \%$ of the sample companies. Equally, in $79 \%$ of the companies, the second and following generations undertake the respective management functions either partially or totally even if the founder remains the lead manager in over 50\% of the companies. The simultaneous convergence of these elements helps in explaining both the negative and the positive relationships found regarding EFP. While, on the one hand, there is a strong cross-generational presence, with the founder in a pre-succession phase, inhibiting the EFP, on the other hand, the family bonds strengthen the occurrence of behaviours such as loyalty and attitudes of pride in the company that convert into commitment and hold members of the family accountable for the success of the respective organisation.

As regards achieving the non-economic objectives, the results convey how FBs experience success whenever they display strong cultures of commitment and values. Family members identifying with the company and corresponding feelings of commitment boost their respective levels of responsibility, leading them to adopt behaviours that are favourable to business success (e.g. increase in assets, longevity) and to protecting the company as a "family" owned firm.

Thus, family influences on FBs cannot only be perceived from positive (e.g., stewardship theory) or negative perspectives (e.g., agency theory). Many FBs survive over generations not only because they are more efficient or profitable, but because they satisfy the socioemotional needs of their owners (Gomez-Mejia et al., 2007) to pursue non-economic objectives.

The theoretical contributions of this research are the following: (1) adaptation of the F-PEC scale for unlisted FBs that adopt one-tier company governance structures; (2) the approach to performance from an economic-financial and non-economic perspective is based on stewardship theory, demonstrating that a culture of commitment allows for the implementation 
and achievement of economic and non-economic objectives of the family group; (3) in unlisted companies, a culture of commitment is considered as the "common factor" for boosting economic and financial performance alongside such objectives as perpetuity and the conservation of the family's heritage and assets.

The current research reveals some limitations, especially: (1) the utilisation of a specific group of FBs, more specifically unlisted SMEs, compromising any generalisation of the results; (2) the application of the F-PEC scale encountered certain limitations as regards business contexts differing to those of the original (Anglo-Saxon) model that underlie its design and conception, especially as regards the governance regimes in effect in the companies and the company type.

\section{Notes}

1 The data refinement process resulted in the elimination of three variables.

2 The data refinement process resulted in the elimination of one variable.

3 Following validation of the MRLM assumptions, the data reported no problems with multicollinearity.

\section{References}

AEF. (n.d.). Associação das Empresas Familiares. Retrieved from http://www.empresasfamiliares.pt/

AEP - Associação Empresarial de Portugal. (2011). Livro Branco da Sucessão Empresarial. O Desafio da Sucessão Empresarial em Portugal. Associação Empresarial de Portugal.

Allouche, J., \& Amann, B. (2000). L'entreprise Familiale : Un état de l'art. Finance, 3(1), 33-79.

Allouche, J., Amann, B., \& Garaudel, P. (2007). Performances et Caractéristiques Financières Comparées des Entreprises Familiales et Non Familiales: le Rôle Modérateur de la Cotation en Bourse et du Degré de Contrôle Actionnarial. In Colloque annuel 2007 AIMS - Montréal 2007.

Anderson, R., \& Reeb, D. (2003). FoundingFamily Ownership and Firm Performance:
Evidence from the S\&P 500. Journal of Finance, 58(3), 1301-1328.

Aparicio, G., Basco, R., Iturralde, T., \& Maseda, A. (2017). An Exploratory Study of Firm Goals in the Context of Family Firms: An Institutional Logics Perspective. Journal of Family Business Strategy, 8(3), 157-169.

Aronoff, C., Astrachan, J., \& Ward, J. (2002). Father to Son: The mediation of Family Firm Succession Conflict (3rd ed.). Marietta, Family Entreprise Publishers.

Astrachan, J., Klein, S., \& Smyrnios, K. (2002). The F-PEC Scale of Family Influence: A Proposal for Solving the Family Business Definition Problem. Family Business Review, 15(1), 45-58.

Astrachan, J., \& Shanker, M. (2003). Family Businesses' Contribution to the U. S. Economy : A Closer Look. Family Business Review, 16(3), 211.

Astrachan, J., \& Zellweger, T. (2008). Performance of Family Firms: A Literature Review and Guidance for Future Research. ZfKE - Zeitschrift Für KMU Und Entrepreneurship, 1-2(56), 1-22.

Basco, R. (2017). "Where do you Want to Take your Family Firm?" A Theoretical and Empirical Exploratory Study of Family Business Goals. Cuadernos de Economía y Dirección de La Empresa, 20(1), 28-44.

Beckhard, R., \& Dyer, W. (1983). Managing Continuity in the Family-owned Business. Organizational Dynamics, 12(1), 5-12.

Bertrand, M., \& Schoar, A. (2006). The Role of Family in Family Firms. The Journal of Economic Perspectives, 20(2), 73-96.

Carlock, R., \& Ward, J. (2001). Strategic Planning for the Family Business. New York: PALGRAVE.

Carney, M., Van Essen, M., Gedajlovic, E., \& Heugens, P. (2015). What do we Know About 
Private Family Firms? A Meta-analytical Review. Entrepreneurship Theory and Practice, 39(3), 513544.

Castillo, J., \& Wakefield, M. (2007). An Exploration of Firm Performance Factors in Family Businesses: Do Families Value Only the "Bottom Line"? Journal of Small Business Strategy, 17(2), 37-51.

Chrisman, J., Chua, J., Kellermanns, F., \& Chang, E. (2007). Are Family Managers Agents or Stewards? An Exploratory Study in Privately Held Family Firms. Journal of Business Research, 60, 1030-1038.

Chrisman, J., Chua, J., Pearson, A., \& Barnett, T. (2012). Family Involvement, Family Influence, and Family-Centered Non-Economic Goals in Small Firms. Entrepreneurship Theory and Practice, 36(2), 267-293.

Chua, J., Chrisman, J., \& Chang, E. (2004). Are Family Firms Born or Made? An Exploratory Investigation. Family Business Review, 17(1), $37-54$.

Chua, J., Chrisman, J., \& Sharma, P. (1999). Defining the Family Business by Behavior. Entrepreneurship Theory and Practice, 23, 19-40.

Chua, J., Chrisman, J., De Massis, A., \& Wang, H. (2018). Reflections on Family Firm Goals and the Assessment of Performance. Journal of Family Business Strategy, 9(2), 107-113.

Chua, J., Chrisman, J., \& Steier, L. (2003). Extending the Theoretical Horizons of Family Business Research. Entrepreneurship Theory and Practice, 27(4), 331-338.

Corbetta, G., \& Montemerlo, D. (1999). Management Issues in Small and Medium-Size Family Businesses : A Comparison of Italy and the United States. Family Business Review, 12(4), 361-374.
Corbetta, G., \& Salvato, C. (2004). The Board of Directors in Family Firms: One Size Fits All? Family Business Review, 17(2), 119-134.

Craig, J., \& Dibrell, C. (2006). The Natural Environment, Innovation, and Firm Performance: A Comparative Study. Family Business Review, 19(4), 275-288.

Davis, J., Schoorman, F., \& Donaldson, L. (1997). Toward a Stewardship Theory of Management. Academy of Management Review, 22(1), 20-47.

Denison, D., Lief, C., \& Ward, J. (2004). Culture in Family-Owned Enterprises: Recognizing and Leveraging Unique Strengths. Family Business Review, 17(1), 61-70.

Donnelley, R. (2006). The Family Business. Harvard Business Review, 1(2), 93-105.

Dyer, W. (1989). Integrating Professional Management into a Family Owned Business. Family Business Review, 2(3), 221-235.

Dyer, W. (2006). Examining the "Family Effect" on Firm Performance. Family Business Review, 19(4), 253-273.

Eddleston, K., Kellermanns, F., \& Sarathy, R. (2008). Resource Configuration in Family Firms: Linking Resources, Strategic Planning and Technological Opportunities to Performance. Journal of Management Studies, 45, 26-50.

Fahed-Sreih, J. (2009). An Exploratory Study on a New Corporate Governance Mechanism: Evidence from Small Family Firms. Management Research News, 32(1), 50-61.

Gallo, M. (1995). Family Businesses in Spain: Tracks Followed and Outcomes Reached by Those Among the Largest Thousand. Family Business Review, 8(4), 145-254.

Gallo, M., \& Ribeiro, V. (1996). A Gestão das Empresas Familiares. Lisboa: Iberconsult. 
Gersick, K., Davis, J., Hampton, M., \& Lansberg, I. (1997). Generation to Generation: Life Cycles of the Family Business. Harvard Business School Press Boston.

Gomez-Mejia, L., Haynes, K., Núñez-Nickel, M., Jacobson, K., \& Moyano-Fuentes, J. (2007). Socioemotional Wealth and Business Risks in Family-Controlled Firms: Evidence from Spanish Olive Oil Mills. Administrative Science Quarterly, 52(1), 106-137.

Gomez-Mejia, L., Nuñez-Nickel, M., \& Gutierrez, I. (2001). The Role of Family Ties in Agency Contracts. Academy of Management Journal, 44(1), 81-95.

González-Cruz, T. F., \& Cruz-Ros, S. (2016). When Does Family Involvement Produce Superior Performance in SME Family Business? Journal of Business Research, 69(4), 1452-1457.

Holt, D., Rutherford, M., \& Kuratko, D. (2010). Advancing the Field of Family Business Research: Further Testing the Measurement Properties of the F-PEC. Family Business Review, 23(1), 76-88.

Holt, D., Pearson, A., Carr, J., \& Barnett, T. (2017). Family Firm(s) Outcomes Model: Structuring Financial and Nonfinancial Outcomes Across the Family and Firm. Family Business Review, 30(2), 182-202.

Jensen, M., \& Meckling, W. (1976). Theory of the Firm: Managerial Behaviour, Agency Costs y Ownership Structure. Journal of Financial Economics, 3(4), 305-360.

Kellermanns, F., Eddleston, K., Sarathy, R., \& Murphy, F. (2010). Innovativeness in Family Firms: a Family Influence Perspective. Small Business Economics, 38(1), 85-101.

Kets de Vries, M. (1994). The Dynamics of Family Controlled Firms: The Good and the Bad News. Organizational Dynamics, 59-71.

Klein, S. (2010). Corporate Governance, Family Business Complexity and Succession. Transfer of Ownership in Private Businesses, 1-20.
Klein, S., Astrachan, J., \& Smyrnios, K. (2005). The F-PEC Scale of Family Influence: Construction, Validation, and Further Implication for Theory. Entrepreneurship Theory and Practice, 29(3), 321-339.

Kowalewski, O., Talavera, O., \& Stetsyuk, I. (2009). Influence of Family Involvement in Management and Ownership on Firm Performance: Evidence from Poland. Family Business Review, 23(1), 45-59.

Labaki, R. (2007). Le concept d'engagement: Une Explication de la Performance des Entreprises Familiales. In Le concept d'engagement: Une explication de la performance des entreprises familiales (1-33). Bordeaux, France: Congrès International de l'AFFI.

Le Breton-Miller, I., \& Miller, D. (2009). Agency vs. Stewardship in Public Family Firms: A Social Embeddedness Reconciliation. Entrepreneurship Theory and Practice, 33(6), 1169-1191.

Lisboa, I. (2018). Sucessão nas Empresas Familiares and o Impacto no Endividamento. Evidência para as PME da Regiáo de Leiria. Revista de Gestão dos Países de Lingua Portuguesa, 17(2), 26-42.

Madison, K., Holt, D., Kellermanns, F., \& Ranft, A. (2016). Viewing Family Firm Behavior and Governance Through the Lens of Agency and Stewardship Theories. Family Business Review, 29(1), 65-93.

Maury, B. (2006). Family Ownership and Firm Performance: Empirical Evidence from Western European Corporations. Journal of Corporate Finance, 12(2), 321-341.

Merino, F., Monreal-Pérez, J., \& Sánchez-Marín, G. (2015). Family SMEs' Internationalization: Disentangling the Influence of Familiness on Spanish Firms' Export Activity. Journal of Small Business Management, 53(4), 1164-1184.

Miralles-Marcelo, J., Miralles-Quirós, M., \& Lisboa, I. (2014). The impact of family control 
on firm performance: Evidence from Portugal and Spain. Journal of Family Business Strategy, 5(2), 156-168.

O’Boyle Jr., E., Pollack, J., \& Rutherford, M. (2012). Exploring the Relation between Family Involvement and Firms' Financial Performance: A Meta-analysis of Main and Moderator Effects. Journal of Business Venturing, 27(1), 1-18.

Patel, P., \& Kellermanns, F. (2010). Family Firm Commitment and Performance: A Moderated Mediation Analysis. The Physical Science Basis (617), 1-6.

Rau, S., Astrachan, J., \& Smyrnios, K. (2018). The F-PEC Revisited: From the Family Business Definition Dilemma to Foundation of Theory. Family Business Review, 31(2), 200-213.

Rutherford, M., Kuratko, D., \& Holt, D. (2008). Examining the Link and Performance: Can the F-PEC Untangle the Family Business Theory Jungle? Entrepreneurship Theory and Practice, (804), 1089-1110.

Schulze, W., Lubatkin, M., Dino, R., \& Buchholtz, A. (2001). Agency Relationships in Family Firms: Theory and Evidence. Organization Science, 12(2), 99-116.

Sciascia, S., \& Mazzola, P. (2008). Family Involvement in Ownership and Management: Exploring Nonlinear Effects on Performance. Family Business Review, 21(4), 331-345.

Shanker, M., \& Astrachan, J. (1996). Myths and Realities: Family businesses' Contribution to the US Economy- a Framework for Assessing Family Business Statistics. Family Business Review, 9(2), 107-123.

Tagiuri, R., \& Davis, J. (1996). Bivalent Attributes of the Family Firm. Family Business Review, 9(2), 199-208.

Tsao, C.-W., Chen, S.-J., \& Wang, Y.-H. (2016). Family Governance Oversight, Performance, and High Performance Work Systems. Journal of Business Research, 69(6), 2130-2137.
Villalonga, B., \& Amit, R. (2006). How do Family Ownership, Control and Management Affect Firm Value? Journal of Financial Economics, (80), 385-417.

Ward, J. (1987). Keeping the Family Business Healthy: How to Plan for Continuing Growth Profitability and Family Leadership. San Francisco: Jossey-Bass Inc.

Westhead, P., \& Howorth, C. (2006). Ownership and Management Issues Associated With Family Firm Performance and Company Objectives. Family Business Review, 19(4), 301-316.

Westhead, P., \& Howorth, C. (2007). 'Types' of Private Family Firms: an Exploratory Conceptual and Empirical Analysis. Entrepreneurship \& Regional Development, 19(5), 405-431.

Williams, R., Pieper, T., Kellermanns, F., \& Astrachan, J. (2018). Family Firm Goals and their Effects on Strategy, Family and Organization Behavior: A Review and Research Agenda. International Journal of Management Reviews, 20, S63-S82.

Zahra, S., Hayton, J., Neubaum, D., Dibrell, C., \& Craig, J. (2008). Culture of Family Commitment and Strategic Flexibility: The Moderating Effect of Stewardship. Entrepreneurship Theory and Practice, 32(6), 1035-1054.

Zellweger, T. (2006). Risk, Return and Value in the Family Firm. University of St. Gallen.

Zellweger, T., Halter, F., \& Frey, U. (2006). Financial Performance of Privately Held Family Firms. In Rencontres de St-Gallen-Center for Family Business - University Of St. GallenSwitzeland.

Zellweger, T., Nason, R., Nordqvist, M., \& Brush, C. (2013). Why Do Family Firms Strive for Nonfinancial Goals? An Organizational Identity Perspective. Entrepreneurship Theory and Practice, 37(2), 229-248. 


\section{Appendix A-Performance scale}

Consider the LAST 3 YEARS in your industry. Regarding the items below, referring to your company's performance against its competitors, indicate your position. Use the following scale:

1-much lower; 2-lower; 3-the same; 4-higher; 5-much higher

In relation to competitors, in your company...

1. Sales growth was

2. The growth in market share was

3. The level of employment was

4. The operating profit margin was

5. The net profitability of the assets was

6. The return on equity (ROE) was

Indicate the degree of importance for each of the following statements using the following scale:

1-not at all important; 2-somewhat important; 3-moderately important; 4-important; 5-highly important

\begin{tabular}{|c|c|c|c|c|c|}
\hline & 1 & 2 & 3 & 4 & 5 \\
\hline 1. Stay independent & & & & & \\
\hline 2. Reduce debt & & & & & \\
\hline 3. Assure the long-term survival of the business & & & & & \\
\hline 4. Balance family concerns and business interests & & & & & \\
\hline 5. Prepare and train a successor & & & & & \\
\hline 6. Increase private or family wealth & & & & & \\
\hline 7. Increase the market value of the business & & & & & \\
\hline 8. Maintain a role for the founder in the business after retirement & & & & & \\
\hline 9. Promote business growth & & & & & \\
\hline 10 Reduce capital dispersion, ensuring its concentration in the family group & & & & & \\
\hline
\end{tabular}

\section{Appendix B - F-Pec Scale}

\section{F-PEC scale (adapted from Astrachan, Klein, \& Smyrnios, 2002)}

1) Indicate the percentage of capital (shares or quotas) held jointly by members of the family and non-family control group:

\begin{tabular}{|l|l|l|l|l|l}
\hline 1.1. & Family members & $\%$ & 1.2. & Non-family members & $\ldots$ \\
\hline
\end{tabular}

2) A empresa tem um Conselho de Administração?

[ ] Yes [ ] No --> go to question no. 3

2) If yes, indicate:

2.1. Number of directors that make up the Board

2.2. No. of board members who are executive directors

2.3. No. of board members who are members of the family group

2.4. No. of executive directors who are members of the family group directors executive directors family members

3) In the company's management board, indicate:

3.1. Number of managers that make up the Board members 
3.2. No. of members of the Board who are members of the family group and assume management functions

4) For each of the following items, please indicate in numbers:

4.1. The generation (or generations) that currently owns the company (1st, 2nd, 3rd etc.)

4.2. The generation (or generations) that, at the moment, manage (s) the company

4.3. The generation (or generations) that, at the moment, is (are) active on governance board

5) What is the frequency of occurrence of the following behaviours, using the following scale:

1-never; 2-rarely; 3-sometimes; 4-often; 5-always

\begin{tabular}{|c|c|c|c|c|c|}
\hline & 1 & 2 & 3 & 4 & 5 \\
\hline 5.1. Your family has influence on your business. & & & & & \\
\hline 5.2. Your family members share similar values. & & & & & \\
\hline 5.3. Your family and business share similar values & & & & & \\
\hline
\end{tabular}

6) Please indicate your degree of agreement for each of the following statements using the following scale:

1-totally disagree; 2-disagree; 3-undecided; 4-agree; 5-totally agree

6.1. Family members support the family business in discussions with friends, employees, and other family members

6.2. Family members feel loyalty to the family business

6.3. Family members are proud to tell others that they are part of the family business

6.4. There is so much to be gained by participating in the family business on a long-term basis

6.5. Family members agree with the family business goals, plans and policies

6.6. Family members really care about the fate of the family business

6.7. Deciding to be involved with the family business has a positive influence on my life

6.8. I support my family's decisions regarding the future of the family business

6.9. Family members are willing to put in a great deal of effort beyond that normally expected to help the family

business be successful family members and managers

\begin{tabular}{|l|l|l|l|l|l|}
\hline $\begin{array}{l}\text { generation } \\
\text { generation }\end{array}$ \\
$\begin{array}{l}\text { generation } \\
\text { generation }\end{array}$ \\
\hline $\begin{array}{l}\text { generation } \\
\text { generation }\end{array}$ & 1 & 2 & 3 & 4 & 5 \\
\hline following scale: & & & & & \\
\hline & & & & & \\
\hline & & & & & \\
\hline
\end{tabular}




\section{Supporting Agencies:}

The views expressed in this paper are those of the authors and do not necessarily represent the views of the institutions with which they are affiliated. The authors acknowledge the financial, research and administrative support from the FCT (UBI: UID/GES/04630/2019; PTDC/EGE-OGE/31246/2017).

\section{Authors:}

1. Catarina Afonso Alves, PhD in Management, University of Beira Interior, Covilhã, Portugal.

E-mail: calves@ipg.pt

ORCID

(iD) 0000-0002-7357-6321

2. Ana Paula Matias Gama, PhD in Finance, ISCTE-IUL University Institute of Lisbon, Lisboa, Portugal. E-mail: amatias@ubi.pt

ORCIID

(iD) 0000-0002-8064-6244

\section{Contribution of each author}

\begin{tabular}{lcc}
\hline Contribution & Catarina Afonso Alves & Ana Paula Matias Gama \\
\hline 1. Definition of research problem & $\sqrt{ }$ & $\sqrt{ }$ \\
2. Development of hypotheses or research questions (empirical studies) & $\sqrt{ }$ \\
3. Development of theoretical propositions (theoretical Work) & & $\sqrt{ }$ \\
4. Theoretical foundation/ Literature review & $\sqrt{ }$ \\
5. Definition of methodological procedures & $\sqrt{ }$ \\
6. Data collection & $\sqrt{ }$ \\
7. Statistical analysis & $\sqrt{ }$ \\
8. Analysis and interpretation of data & $\sqrt{ }$ \\
9. Critical revision of the manuscript & $\sqrt{ }$ \\
10. Manuscript Writing & $\sqrt{ }$ \\
11. Other (please specify which) & & $\sqrt{ }$ \\
\hline
\end{tabular}

